\title{
Acute colchicine overdose: report of three cases
}

\author{
A. Aghabiklooei ${ }^{1,2}$, N. Zamani' ${ }^{2}$ H. Hassanian-Moghaddam², \\ S. Nasouhi' ${ }^{2}$, M. Mashayekhian ${ }^{2}$ \\ ${ }^{1}$ Department of Forensic Medicine, Iran University of Medical Sciences, Tehran; \\ ${ }^{2}$ Department of Clinical Toxicology, Loghman-Hakim Hospital, Shahid Beheshti University \\ of Medical Sciences, Tehran, Iran
}

\begin{abstract}
SUMMARY
Intentional acute toxicity by colchicine is not common but accompanies a high rate of complications and mortality. It is generally assumed to be an emergency in clinical toxicology. Rapid diagnosis and treatment can prevent death. The most common causes of death in this toxicity are acute cardiac failure, shock, and dysrhythmias with hematopoietic complications occurring in later stages. We report three cases of acute colchicine toxicity, two of which expired, with different presenting and ongoing signs and symptoms. We aimed to define the different possible clinical manifestations of the toxicity and review the probable treatments available for these patients.
\end{abstract}

Key words: Colchicine, Acute toxicity, Fulminant aplasia, Disseminated intravascular coagulopathy, Outcome, Treatment, Acute respiratory distress syndrome.

Reumatismo, 2013; 65 (6): 307-311

\section{INTRODUCTION}

C olchicine is a lipophilic plant alkaloid medication still used for the treatment of familial Mediterranean fever, gout, amyloidosis, Behcet's syndrome, pericarditis, arthritis, pulmonary fibrosis, vasculitis, billiary cirrhosis, pseudogout, certain spondyloarthropathies, calcinosis, and scleroderma. Epidemiologic data on colchicine poisoning is missing. Poisoning with this medication generally occurs unintentionally in the adults due to its narrow therapeutic index. Almost $10 \%$ of the patients are reported to have severe toxicity or die (1). Its mechanism of action is inhibition of cell mitosis and interference with intracellular transport mechanisms and maintenance of cell structure as well as being a competitive antagonist of $\mathrm{GABA}_{\mathrm{A}}$ (2).

It is generally assumed that ingestion of a dose of $0.8 \mathrm{mg} / \mathrm{kg}$ can kill the patient; however, recent data suggests that death can occur with smaller doses (1). Death has been reported in ingestions varying from 7 to 25 $\mathrm{mg}$, although survival has been reported in a patient with an oral ingestion dose of 60 mg (2). Chronic renal failure by decreasing hepatic and renal excretion of the drug may result in increased plasma concentrations of colchicine and develop further colchicine intoxication (3).

We report three cases of acute colchicine poisoning referred to our center with different signs and symptoms. Since this is a rather rare toxicity and can be fatal, we aimed to define the different possible clinical manifestations of the toxicity and review the probable treatments available for these patients.

\section{CASE 1}

The patient was a 10 -year old boy who had ingested thirty 1-mg colchicine tablets in a try to discover the effects of different medications on the body.

He did not mention consumption of any other medication. He was a known case of G6PD deficiency. Four hours after the ingestion, he referred to a local hospital (in Zahedan) with retractable nausea and vomiting. After gastric lavage and adminis-
Corresponding author: Hossein Hassanian-Moghaddam Loghman-Hakim Hospital Karegar Street, Tehran, Iran E-mail: Hassanian@sbmu.ac.ir 
tration of charcoal and sorbitol, he was referred to our center due to decreased level of consciousness.

He was admitted to our center on the second day post-ingestion with the following vital signs: heart rate $=115 / \mathrm{min}$, blood pressure $(\mathrm{BP})=90 / 70 \mathrm{mmHg}$, respiratory rate $=48 / \mathrm{min}$ and temperature $=36.8^{\circ} \mathrm{C}$. Multiple doses of activated charcoal were initiated.

He developed epigastric tenderness, tachycardia, hypotension (BP of $85 / 65 \mathrm{mmHg}$ ), fever, and gross hematuria and was intubated within hours because of severe tachypnea.

In electrocardiography (ECG), nonspecific $\mathrm{T}$ wave changes were observed in leads $\mathrm{V} 1$ and V2 that were soon detected in all precordial leads. Twenty-six hours after the ingestion, he was put on continuous renal replacement therapy continuing for $20 \mathrm{~h}$. The patient then developed acute upper gastrointestinal hemorrhage, thrombocytopenia, and rhabdomyolysis which did not respond to the conservative managements including administration of vitamin $\mathrm{K}$, fresh frozen plasma, platelets, $\mathrm{N}$-acetylcysteine, and intravenous (IV) fluids. On the third day post-ingestion, he experienced icter, severe agitation, pre-orbital edema, eyelash ecchymosis, and bleeding from the IV lines. He died on the same day because of acute respiratory distress syndrome (ARDS) and disseminated intravascular coagulopathy (DIC).

\section{CASE 2}

The patient was a 37-year old woman with unspecified rheumatismal disease who was on colchicine for several years (one 1-mg tablet daily) and had stopped consuming the medication since three months earlier. She had intentionally ingested 38 tablets. Two hours after the ingestion, she vomited and eight hours later, she was brought to our emergency department with retractable nausea, vomiting and abdominal pain. On admission, she was completely conscious and a little dehydrated. Vital signs were normal. After administration of a dose of charcoal and sorbitol, she was admitted to the intensive care unit. Multiple doses of activated charcoal were initiated. On the following day, she was complaining of generalized weakness, abdominal pain, and vomiting.

She appeared pale and had generalized mild abdominal tenderness. Symptom therapy with hyoscine, methoclopramide, and ranitidine was performed. Twenty hours later, she developed hypotension, bradycardia, loss of consciousness, cyanosis, and dyspnea and was intubated and mechanically ventilated.

Severe metabolic acidosis ensued which was treated by sodium bicarbonate. Almost 32 and $36 \mathrm{~h}$ post-ingestion, the patient developed severe bradycardia and cardiac arrest, respectively. Cardiopulmonary resuscitation was performed which was not successful and the patient died.

\section{CASE 3}

The patient was a 25-year old nurse who had intentionally ingested $251-\mathrm{mg}$ colchicine tablets and referred to us with vomiting four hours post-ingestion. She was admitted and observed for $24 \mathrm{~h}$ without developing severe toxicity signs and symptoms. Multiple doses of activated charcoal had also been administered during hospitalization. Five days after discharge, she referred to a physician with the chief compliant of sore throat and earache and was re-referred to us due to thrombocytopenia (platelet count $=59,000$ ). She was restless and complained of severe back pain on admission. After administration of five platelet packs and on the third day of admission, her white blood cell (WBC) count was reported to be 3200 . Thirty microunits of granulocyte colony stimulating factors (GCSF) were subcutaneously given. After administering two units of GCSF, WBC count reached 5200. She improved with the conservative treatment and was discharged 5 days later in good clinical condition and completely symptom-free. A summary of the lab tests of all three patients is brought in Table I. 
Table I - Summary of the patient's lab tests.

\begin{tabular}{|c|c|c|c|c|c|c|c|c|c|c|c|c|c|c|}
\hline \multirow{2}{*}{\multicolumn{2}{|c|}{ Lab test }} & \multicolumn{5}{|c|}{ Case 1} & \multicolumn{3}{|c|}{ Case 2} & \multicolumn{5}{|c|}{ Case 3} \\
\hline & & $1-12 \mathrm{~h}$ & $12-24 \mathrm{~h}$ & $24-36 \mathrm{~h}$ & $36-48 \mathrm{~h}$ & $48-60 \mathrm{~h}$ & $1-12 \mathrm{~h}$ & $12-24 \mathrm{~h}$ & $24-36 \mathrm{~h}$ & $1-12 \mathrm{~h}$ & $12-24 \mathrm{~h}$ & $24-48 \mathrm{~h}$ & $48-72 \mathrm{~h}$ & $72-96 \mathrm{~h}$ \\
\hline \multicolumn{2}{|c|}{$\begin{array}{l}\text { White blood cell } \\
\text { count } \times 10^{3} \mathrm{\mu L} \\
\end{array}$} & 14.7 & 20.3 & 10.4 & 22 & 12 & 20.8 & 77 & 30.7 & 89 & 62 & 45 & $\begin{array}{l}18 \text { Lym } \\
54 \%\end{array}$ & $\begin{array}{l}5.2 \text { Lym } \\
11.2 \%\end{array}$ \\
\hline \multicolumn{2}{|c|}{$\begin{array}{l}\text { Red blood cell } \\
\text { count } \times 10^{6} \mu \mathrm{L}\end{array}$} & 5.27 & 5.37 & 4.87 & 3.24 & 2.04 & 4.71 & 5.13 & 4.21 & 4.71 & 4.63 & 4.05 & 3.97 & 4.21 \\
\hline \multicolumn{2}{|c|}{$\begin{array}{l}\text { Hemoglobin (mg/ } \\
\text { dL) }\end{array}$} & 15.6 & 15.6 & 12.5 & 5.8 & 5.6 & 14.3 & 14.2 & 11.8 & 13.8 & 13.7 & 12.7 & 12.3 & 12.7 \\
\hline \multirow{2}{*}{\multicolumn{2}{|c|}{\begin{tabular}{|l|} 
Hematocrit (\%) \\
MCV \\
\end{tabular}}} & 43.1 & 43.9 & 38.3 & 30.3 & 17.1 & 39.7 & 44.1 & 36.2 & 37.5 & 37.5 & 34.9 & 34.3 & 35.7 \\
\hline & & 81.8 & 81.8 & 78.6 & 81.2 & 76.2 & 84.3 & 86 & 86 & 80 & 80.99 & 86.17 & 84.3 & N/A \\
\hline \multicolumn{2}{|l|}{$\mathrm{MCHC}$} & 36.2 & 35.5 & 25.7 & 23.2 & 24.2 & 33.8 & 32.2 & 28 & 29.4 & 36.5 & N/A & $N / A$ & N/A \\
\hline \multicolumn{2}{|c|}{ Platelet $\times 10^{3} \mu \mathrm{L}$} & 223 & 237 & 76 & 42 & 35 & 263 & 21 & 204 & 116 & 59 & 29 & 20 & 22 \\
\hline \multicolumn{2}{|c|}{$\begin{array}{l}\text { Lactate } \\
\text { dehydrogenase }\end{array}$} & 4078 & 5600 & 10,000 & 5991 & N/A & N/A & 1608 & 4361 & 4120 & N/A & 5180 & $\mathrm{~N} / \mathrm{A}$ & 2120 \\
\hline \multicolumn{2}{|c|}{$\begin{array}{l}\text { Creatine } \\
\text { phosphokinase }\end{array}$} & 1826 & N/A & 3360 & 1264 & N/A & 154 & N/A & 459 & N/A & $\mathrm{N} / \mathrm{A}$ & 2038 & N/A & 1381 \\
\hline \multicolumn{2}{|c|}{$\begin{array}{l}\text { Creatine kinase- } \\
\text { MB }\end{array}$} & N/A & N/A & N/A & N/A & N/A & N/A & 31 & N/A & N/A & $\mathrm{N} / \mathrm{A}$ & N/A & N/A & $\begin{array}{l}50 \\
(<24)\end{array}$ \\
\hline \multicolumn{2}{|c|}{$\begin{array}{l}\text { Blood urea } \\
\text { nitrogen }(\mathrm{mg} / \mathrm{dL})\end{array}$} & 12.7 & N/A & 35 & 52 & 10 & 24.5 & N/A & 36 & 18 & N/A & 16 & N/A & N/A \\
\hline \multicolumn{2}{|c|}{ Creatinine (mg/dL) } & 0.67 & $\mathrm{~N} / \mathrm{A}$ & 0.9 & 0.6 & 0.7 & 1.4 & $\mathrm{~N} / \mathrm{A}$ & 1.9 & 1.01 & $\mathrm{~N} / \mathrm{A}$ & 1.05 & $\mathrm{~N} / \mathrm{A}$ & $\mathrm{N} / \mathrm{A}$ \\
\hline \multicolumn{2}{|c|}{$\begin{array}{l}\text { Aspartate } \\
\text { trasnaminase } \\
(\mathrm{U} / \mathrm{L})\end{array}$} & 199 & 470 & 640 & 419 & 399 & N/A & 20 & N/A & 48 & N/A & 343 & 240 & 237 \\
\hline \multicolumn{2}{|c|}{$\begin{array}{l}\text { Alanine } \\
\text { transaminase } \\
\text { (U/L) }\end{array}$} & 34 & 63 & 80 & 40 & 26 & N/A & 41 & N/A & 34 & N/A & 60 & 119 & 114 \\
\hline \multirow{2}{*}{\multicolumn{2}{|c|}{$\begin{array}{l}\text { Alkaline } \\
\text { phosphatase (U/L) } \\
\text { Prothrombin time }\end{array}$}} & 1197 & 1200 & 1590 & 557 & 312 & N/A & 721 & N/A & 492 & N/A & 665 & N/A & 150 \\
\hline & & 16 & 22 & 33 & 17.7 & N/A & 26.7 & 45.9 & N/A & 13.1 & N/A & 13.4 & N/A & 12.8 \\
\hline \multicolumn{2}{|c|}{$\begin{array}{l}\text { Partial } \\
\text { thromboplastin } \\
\text { time }\end{array}$} & 30 & 38 & 40 & 79 & N/A & 45 & 68 & N/A & 29.2 & N/A & 29 & N/A & 26 \\
\hline \multirow{3}{*}{\multicolumn{2}{|c|}{$\begin{array}{l}\text { International } \\
\text { normalized ratio } \\
\text { Calcium (mEq/L) } \\
\text { Sodium (mEq/L) }\end{array}$}} & 1.5 & 2.9 & 5.88 & 1.92 & N/A & 4.06 & 4.8 & N/A & 1.32 & N/A & 1.36 & N/A & 1.4 \\
\hline & & N/A & N/A & 7.8 & 8.1 & $\mathrm{~N} / \mathrm{A}$ & $-N / A$ & N/A & 6.8 & N/A & N/A & & $\mathrm{N} / \mathrm{A}$ & $\mathrm{N} / \mathrm{A}$ \\
\hline & & 138 & 133 & 138 & 139 & 138 & 145 & N/A & 145 & N/A & $\mathrm{N} / \mathrm{A}$ & 142 & $\mathrm{~N} / \mathrm{A}$ & 141 \\
\hline \multicolumn{2}{|c|}{$\begin{array}{l}\text { Potassium } \\
\text { (mEq/L) }\end{array}$} & 3.6 & N/A & 3.7 & 4 & 4 & 3.5 & N/A & 3.6 & N/A & N/A & 3.6 & N/A & 3.3 \\
\hline \multicolumn{2}{|c|}{$\begin{array}{l}\text { Blood sugar (mg/ } \\
\text { dL) }\end{array}$} & N/A & 60 & 50 & 130 & 203 & 85 & $\mathrm{~N} / \mathrm{A}$ & 89 & N/A & N/A & 99 & N/A & 104 \\
\hline & & N/A & N/A & 190 & 80 & N/A & N/A & 343 & N/A & N/A & N/A & N/A & N/A & 91 \\
\hline $\begin{array}{l}\text { Bilirubin } \\
\mathrm{dL} \text { ) }\end{array}$ & total (mg/ & N/A & N/A & 1.5 & 1.4 & N/A & N/A & N/A & 0.4 & N/A & N/A & 0.4 & N/A & 1.4 \\
\hline $\begin{array}{l}\text { Bilirubin } \\
\text { (mg/dL) }\end{array}$ & direct & N/A & N/A & 0.3 & 0.2 & N/A & N/A & N/A & 0.2 & N/A & N/A & 0.2 & N/A & 0.3 \\
\hline G6PD & & $\mathrm{N} / \mathrm{A}$ & Deficient & $\mathrm{N} / \mathrm{A}$ & $\mathrm{N} / \mathrm{A}$ & N/A & $\mathrm{N} / \mathrm{A}$ & $\mathrm{N} / \mathrm{A}$ & $\mathrm{N} / \mathrm{A}$ & $\mathrm{N} / \mathrm{A}$ & N/A & N/A & N/A & $\mathrm{N} / \mathrm{A}$ \\
\hline Arterial & $\mathrm{pH}$ & N/A & 7.36 & 7.34 & 7.28 & 6.98 & 7.36 & 7.32 & N/A & N/A & 7.35 & N/A & N/A & 7.48 \\
\hline blood & $\mathrm{PCO} 2$ & $\mathrm{~N} / \mathrm{A}$ & 28.3 & 19.1 & 55.2 & 120.8 & 23.2 & 24.1 & $\mathrm{~N} / \mathrm{A}$ & $\mathrm{N} / \mathrm{A}$ & 33 & $\mathrm{~N} / \mathrm{A}$ & N/A & 26.9 \\
\hline gases & PO2 & $\mathrm{N} / \mathrm{A}$ & 239 & 72.4 & 44.2 & 35.6 & 89 & 79 & N/A & N/A & $\mathrm{N} / \mathrm{A}$ & $\mathrm{N} / \mathrm{A}$ & N/A & 45.3 \\
\hline & $\mathrm{HCO} 3$ & $N / A$ & 15.6 & 10.4 & 20.6 & 26.4 & 13.3 & 7.1 & 10.0 & N/A & 17.2 & N/A & $\mathrm{N} / \mathrm{A}$ & 20.6 \\
\hline & $\mathrm{BE}$ & N/A & -8.1 & \begin{tabular}{|l|}
-12.3 \\
\end{tabular} & -3.2 & -5.3 & \begin{tabular}{|l|} 
\\
\end{tabular} & \begin{tabular}{|l|} 
\\
\end{tabular} & -26.5 & $\mathrm{~N} / \mathrm{A}$ & $\mathrm{N} / \mathrm{A}$ & $\mathrm{N} / \mathrm{A}$ & $\mathrm{N} / \mathrm{A}$ & -3 \\
\hline Urine & SG & N/A & 1010 & N/A & 1018 & $\mathrm{~N} / \mathrm{A}$ & N/A & 1015 & 1020 & $\mathrm{~N} / \mathrm{A}$ & $\mathrm{N} / \mathrm{A}$ & N/A & $\mathrm{N} / \mathrm{A}$ & N/A \\
\hline malysis & Protein & $\mathrm{N} / \mathrm{A}$ & + & $\mathrm{N} / \mathrm{A}$ & N/A & $\mathrm{N} / \mathrm{A}$ & N/A & $\mathrm{N}$ & ++ & $\mathrm{N} / \mathrm{A}$ & $\mathrm{N} / \mathrm{A}$ & $\mathrm{N} / \mathrm{A}$ & $\mathrm{N} / \mathrm{A}$ & $\mathrm{N} / \mathrm{A}$ \\
\hline & Glucose & N/A & ++ & $\mathrm{N} / \mathrm{A}$ & N/A & $\mathrm{N} / \mathrm{A}$ & N/A & $\mathrm{N}$ & + & N/A & $\mathrm{N} / \mathrm{A}$ & $\mathrm{N} / \mathrm{A}$ & $N / A$ & $\mathrm{~N} / \mathrm{A}$ \\
\hline & RBC & N/A & Many & $\mathrm{N} / \mathrm{A}$ & 5 & $\mathrm{~N} / \mathrm{A}$ & N/A & $\mathrm{N}$ & +++ & N/A & N/A & $\mathrm{N} / \mathrm{A}$ & $\mathrm{N} / \mathrm{A}$ & $\mathrm{N} / \mathrm{A}$ \\
\hline & Ketone & $\mathrm{N} / \mathrm{A}$ & + & $\mathrm{N} / \mathrm{A}$ & $\mathrm{N} / \mathrm{A}$ & N/A & $\mathrm{N} / \mathrm{A}$ & $\mathrm{N} / \mathrm{A}$ & $\mathrm{N} / \mathrm{A}$ & $\mathrm{N} / \mathrm{A}$ & $\mathrm{N} / \mathrm{A}$ & N/A & N/A & $\mathrm{N} / \mathrm{A}$ \\
\hline & WBC & N/A & 5 & $\mathrm{~N} / \mathrm{A}$ & 3 & N/A & N/A & 6-8 & $2-3$ & N/A & N/A & 10 & N/A & N/A \\
\hline
\end{tabular}




\section{DISCUSSION}

Although a safe medication when administered according to the guideline protocols, colchicine can cause serious systemic toxicity in overdoses and accompanies a high mortality rate (4). High mortality rate is expected when ingestion exceeds $0.5 \mathrm{mg} / \mathrm{kg}$ in acute cases, as in our first and third cases (4). Generally, it is considered that a dose of 0.5 to $0.8 \mathrm{mg} / \mathrm{kg}$ is toxic and a dose higher than $0.8 \mathrm{mg} / \mathrm{kg}$ is lethal (5). However, no clear-cut limit exists between the safe, toxic, and fatal doses and patients have survived even after ingestion of as much as 60 $\mathrm{mg}$ of this medication (2). Mullins and colleagues suggested that colchicine contributed to the death of almost one third of the patients who were treated by Colchicines for some reason in the hospital (6).

Drug-drug reactions are considered as a very important cause of enhanced toxicity due to the interaction with isoenzyme $3 \mathrm{~A} 4$ of the liver cytochrome P450. Of the medications that can cause enhanced toxicity by colchicine are cyclosporine $(3,7$, 8 ), verapamil (5), erythromycin (5), lovastatin (5), pravastatin (8), and azithromycin (8). Co-administration of colchicine with statins may lead to statin-associated autoimmune-necrotizing myopathy, causing myopathy and induced further rhabdomyolysis (9). Even, positive past medical history for alcoholism and hepatitis $\mathrm{C}$ have been suggested to negatively enhance the toxicity caused by colchicine (10). All of our patients were otherwise healthy and did not consume any medication that could interact with colchicine. This again emphasizes the potential power of colchicine to be fatal even without the effect of the other medications.

The main mechanism of action is binding to intracellular tubulin and preventing formation of the microtubules that arrests mitosis (11). Other actions include inhibition of the release of histamine and secretion of insulin, depression of the central respiratory system, stimulation of the central vasomotor system inducing hypertension, and increased reaction to the sympathomimetic agents (12).
Colchicine poisoning is generally described to be triphasic: gastrointestinal (GI) irritation ( 0 to $24 \mathrm{~h}$ post-ingestion) persisting for 12-24 h, widespread organ system dysfunction (particularly in the bone marrow) persisting for several days, and finally, recovery or death which occurs within one week. Hematopoietic effects of colchicine begin with leukocytosis, followed by profound leukopenia and pancytopenia that begins almost 48 to $72 \mathrm{~h}$ post-ingestion (1). The cardiac effects include dysrhythmias and cardiac arrest, hypovolemia and shock, and direct effect on the cardiac muscle resulting in rhabdomyolysis (1).

Other possible signs and symptoms of Colchicines toxicity are myopathy, neuropathy, combined myoneuropathy (chronic toxicities), ARDS, neurologic effects (delirium, stupor, coma, and seizures), renal insufficiency, and electrolyte abnormalities. Of the more uncommon signs are adrenal hemorrhages, DIC, pancreatitis, and liver dysfunction (1). All three patients of ours presented with severe GI signs and symptoms; however, after that, each patient continued to show different signs and symptoms: one with DIC, second with bradycardia and hemodynamic instability, and the last one with profound thrombocytopenia.

As shown in Table I, all cases experienced leukocytosis, increased hemoglobin and red blood cell (RBC) counts within the first $12 \mathrm{~h}$ that reversed after the $24^{\text {th }}$ post-ingestion hour. Lactate dehydrogenase increased from the second day post-ingestion on and a mild lactic acidosis developed after the first $12 \mathrm{~h}$ showing the possible mechanism of entering the anaerobic metabolism.

All three cases showed increased aspartate transaminase without changes in alanine transaminase, increased alkaline phosphatase, and proteinuria as well as RBCuria. This is in contrast with the previous literature that suggested a treating role for colchicine in the proteinuria and hemoglobinuria induced by different diseases in internal medicine (13-15). The interesting part is that the two patients, who expired, had developed coagulopathy, while the third case did not. This may suggest a 
better prognosis in the patients who do not experience coagulopathy during the course of their toxicity.

Patients should be admitted to the hospital after colchicine overdose and be observed for at least $24 \mathrm{~h}$. If remain without symptoms, they can be discharged.

Treatment is limited to conservative management. Gastric lavage and charcoal administration are advocated even several hours after ingestion (up to $24 \mathrm{~h}$ ) (4). Multi-dose activated charcoal has been suggested because of the enterohepatic recirculation of the medication (16). Admission of the patients in the Intensive Care Unit for observation and management of the possible arrhythmias, monitoring of the vital signs, ECGs, hematological and biochemical parameters, correction of the electrolyte and acid-base abnormalities, mechanical ventilation, and administration of blood products and GCSF are generally recommended (4).

One limitation of our study was that we could not determine the serum level of colchicine and our diagnosis was completely based on the given history. However, this measurement is not readily available even in the developed world, in which the diagnosis is generally based on the history and clinical signs and symptoms (1). Further studies on the effects of colchicine on urine analysis and the prognostic factors of its toxicity are warranted.

\section{Contributions}

AA carried out the design; HHM coordinated the study; SN and MM participated in the management of the patients and provided assistance in the design of the study; $\mathrm{HHM}$ and NZ prepared the manuscript. All authors have read and approved the content of the manuscript.

\section{REFERENCES}

1. Schier JG. Colchicine, podophillyn, and the vinca alkaloids. In: Nelson LS, Lewin NA, Howland MA, Hoffman RS, Goldfrank LR, Flomenbaum NE, eds. Goldfrank's toxicologic emergencies. New York: McGraw-Hill 2011; 537-48.

2. Baud FJ, Sabouraud A, Vicaut E, Taboulet P, Lang J, Bismuth C, et al. Brief report: treatment of severe colchicine overdose with colchicine-specific Fab fragments. N Engl J Med. 1995; 332: 642-5.

3. Eleftheriou G, Bacis G, Fiocchi R, Sebastiano R. Colchicine-induced toxicity in a heart transplant patient with chronic renal failure. Clin Toxicol (Phila) 2008; 46: 827-30.

4. Finkelstein Y, Aks SE, Hutson JR, Juurlink DN, Nguyen P, Dubnov-Raz G, et al. Colchicine poisoning: the dark side of an ancient drug. Clin Toxicol (Phila) 2010; 48: 407-14.

5. Montiel V, Huberlant V, Vincent MF, Bonbled F, Hantson P. Multiple organ failure after an overdose of less than $0.4 \mathrm{mg} / \mathrm{kg}$ of colchicine: role of coingestants and drugs during intensive care management. Clin Toxicol (Phila) 2010; 48: $845-8$.

6. Mullins M, Cannarozzi AA, Bailey TC, Ranganathan P. Unrecognized fatalities related to colchicine in hospitalized patients. Clin Toxicol (Phila) 2011; 49: 648-52.

7. Eleftheriou G, Bacis G, Fiocchi R, Sebastiano R. Colchicine-induced toxicity in a heart transplant patient with chronic renal failure. Clin Toxicol (Phila) 2008; 46: 827-30.

8. Bouquié R, Deslandes G, Renaud C, Dailly E, Haloun A, Jolliet P. Colchicine-induced rhabdomyolysis in a heart/lung transplant patient with concurrent use of cyclosporin, pravastatin, and azithromycin. J Clin Rheumatol. 2011; 17: 28-30.

9. Mohassel P, Mammen AL. The spectrum of statin myopathy. Curr Opin Rheumatol. 2013; 25: 747-52.

10. Mullins ME, Carrico EA, Horowitz BZ. Fatal cardiovascular collapse following acute colchicine ingestion. J Toxicol Clin Toxicol. 2000; 38: 51-4.

11. Ben-Chetrit E, Levy M. Colchicine: 1998 update. Semin Arthritis Rheum. 1998; 28: 4859. 